NASA Technical Memorandum 103284

\title{
Photovoltaic Options for Solar Electric Propulsion
}

Paul M. Stella Jet Propulsion Laboratory

Pasadena, California

and

Dennis J. Flood

Lewis Research Center

Cleveland, Ohio

Prepared for the

26th Joint Propulsion Conference

cosponsored by the AIAA, ASME, SAE, and ASEE

Orlando, Florida, July 16-18, 1990

\section{N/Sก}

(NASA-TM-103294) PHUTOVULTAIT OPTIONS FOR

$N 91-11061$ SOLAR LLECTSIC PKOPULSION (NVASA) 16 P 


\title{
PHOTOVOLTAIC OPTIONS FOR SOLAR ELECTRIC PROPULSION
}

\author{
Paul M. Stella \\ Jet Propulsion Laboratory \\ Cal ifornia Institute of Technology \\ Pasadena, California 91109 \\ and \\ Dennis J. Flood \\ National Aeronautics and Space Administration \\ Lewis Research Center \\ Cleveland, Ohio 44135
}

\begin{abstract}
SUMMARY
During the past decade a number of advances have occurred in solar cell and array technology. These advances have lead to an improvement in performance for both conventional space arrays and for advanced technology arrays. Performance enhancements have occurred in power density, specific power, and environmental capability. This paper will discuss both state-of-the-art and advanced development cell and array technology. Present technology will include rigid, roll-out, and foldout flexible substrate designs, with silicon and GaAs solar cells. The use of concentrator array systems will also be discussed based on both DOD efforts and NASA work. The benef its of advanced lightweight array technology, for both near term and far term utilization, and of advanced high efficiency, thin, radiation resistant cells will be examined. This will include gallium arsenide/germanium, indium phosphide, and thin film devices such as copper indium diselenide.
\end{abstract}

\section{INTRODUCT ION}

Photovoltaics have been the preferred power source for the majority of spacecraft, including military, commercial, and scientific missions. Applications have ranged $f$ rom a wide variety of earth orbiting to planetary uses out to Mars and inbound to the orbit of Mercury. Photovoltaics have evolved dramatically since the earliest applications over 30 years ago and power capabilities are now more than three orders of magnitude greater than the first primitive uses. Among the reasons for the longevity of PV are the demonstrated reliability, the continued technology improvements, and the adaptability to a diverse range of spacecraft physical and environmental requirements. As a result, the spacecraft designer is of ten confronted with a wide variety of PV options for any particular application. These options are typically evaluated on the basis of performance (area, mass, degradation) risk, and cost. The options include variations in both the basic array structural composition and the cell. These will be discussed in the following sections. Both existing state-of-the-art and emerging technologies will be examined. A brief section will then examine the relative performance of selected cell/array designs for some representative solar electric propulsion (SEP) applications. 


\section{Solar Array Options}

Solar arrays have been formed both by attaching the solar cell electrical circuit (cells, interconnectors, covers, adhesives, wiring, and insulation) directly to a rigid substrate and by attaching to a flexible substrate (blanket) that is in turn supported by an external structure. In addition, there are combinations of the two basic array methods, i.e., lightweight rigid substrates that rely on support from an additional external structure.

The earliest arrays were generally mounted directly to the spacecraft surface (ref. 1). This can be very mass effective since a separate substrate is not required. In addition, the spacecraft body can shield the solar cell rear surface from radiation. However, the available array area is limited and in general, only limited power can be achieved by a body mounted array. Some modern examples of body mounted arrays do exist with very respectable power levels. An example is the SBS-1A communications satellite where the cells are fixed to a large spinning cylindrical satellite (ref. 2). In this case additional surface has been provided by using a cylindrical "skirt" that extends down from the original satellite cylindrical body. Strictly speaking this approach combines body mounted circuits with circuits on a deployable rigid array (the "skirt"). Specific performance $(\mathrm{W} / \mathrm{kg})$ of these designs is not commonly presented since it is very difficult to assign a structural mass to the array that is not shared by the spacecraft proper. However, if only the electrical circuit mass is included then extremely high specific power can be achieved. As impressive as these satellites have been little future growth potential is expected. Furthermore, for the purpose of a SEP mission it is not clear that a high surface area spacecraft is consistent with the desirability for low spacecraft mass.

In order to escape the constraints of body mounting, spacecraft early on utilized deployable rigid panels. The largest example of this type was the Skylab with its (planned) $23 \mathrm{~kW}$ from a number of panels contained in two separate arrays, the OWS array, and the ATM array. The former array graphically demonstrated one of the concerns of deployable arrays - i.e., improper deployment, leading to the loss of an entire wing.

The rigid deployable array typically consists of an aluminum honeycomb center with aluminum facesheets. The upper facesheet is then covered with an insulator and the cell circuits are bonded to the insulator. Cell wiring can be done on the front surface or may be passed to the panel rear side using feedthroughs or holes in order to reduce overall panel area. The panel can be painted where not covered with solar cells to improve the thermal performance. Through the years there has been a gradual, al though not always steady $t$ rend to reduce array mass, both at the cell circuit level and at the substrate level. The use of higher efficiency and thinner cells and lightweight honeycomb cores and facesheets has provided a mass reduction. This has resulted in some increase in array design complexity since the weight reductions have placed designs closer to material and structural operating limits. In the most advanced lighweight rigid designs the substrate properties can be varied across the panel in accordance with local loads. This obviously requires a sophisticated knowledge of materials and environmental interactions.

Although simple panel designs may consist of single substrates with appropriate solar array drives and standoffs, the need for higher power has also brought about the development of multipanel array wings, requiring secondary 
deployments for full deployment. As part of the mass reduction tradeoff, lightweight rigid designs also reduce some of the cell backside radiation protection when compared to heavier designs. In the case of the latter, it is of ten possible to avoid any consideration of rear side introduced radiation damage. For the lightest rigid designs that is not completely true.

The specific performance of rigid arrays can be altered significantly by choice of cell, cover, manufacturing process, and substrate, and al though this typically results in 20 to $30 \mathrm{~W} / \mathrm{kg}$ specific performance (BOL), it has occasionally fallen below $10 \mathrm{~W} / \mathrm{kg}$. At the other extreme some of the advanced designs have the capability of nearly 40 to $50 \mathrm{~W} / \mathrm{kg}$ with thin silicon cells. In particular have been a number of advance technology designs developed by European manufacturers, al though U.S. manufacturers are showing increased interest in low mass design development. Those very lightweight designs, as mentioned earlier require a sophisticated design and manufacturing capability. In addition, the handling restrictions approach the care required for advanced flexible blanket designs.

The third type of array is referred to as the flexible deployable array. Such arrays are best applicable to high power systems since a relatively high fraction of array mass must go into the protective storage structure and employment/support system. In general, these components do not change significantly as the overall array size changes and are consequently of reduced mass fraction as the array size/power level increases.

Although not as commonly used as rigid array technology, flexible designs have been in limited use for nearly 20 years. The earliest application was the FRUSA (flexible roll up array) flown in 1971 (ref. 3). This design relied on the use of a flexible Kapton substrate that was rolled from a cylindrical drum. Deployment was effected by tubular stainless steel members, BISTEMs, that unrolled the blanket out through attachment to a spreader bar at the end of the blanket. Based on the use of $150 \mu \mathrm{m}$ thick solar cells of low efficiency the approximately $1 \mathrm{~kW}$ FRUSA provided $45 \mathrm{~W} / \mathrm{kg}$. Estimates of FRUSA specific power, utilizing more recent high efficiency thin silicon cells, indicate a capability of nearly $90 \mathrm{~W} / \mathrm{kg}$, a remarkable result for such a small flexible array. The only other roll up flight array design is that for the space telescope, which for a variety of reasons, not the least of which is the need for man rating, falls short of the original FRUSA specific performance, even though utilizing more advanced cell technology.

An alternative to the roll out concept is the fold out design in which the substrate/circuits fold in an accordion like fashion. Early designs of this type include the European/Canadian CTS array, which combined a fold out blanket with a BISTEM boom, the U.S. SAE array (tested from the shut le in 1984), and the European Olympus array. The later two both utilized a coilable longeron deployable boom for support. The coilable longeron boom provides higher strength and stiffness per unit weight although the packaged volume is larger. Advantages of this boom are more evident for larger array sizes. The highest specific performance for these designs was achieved by the SAE with a projected level of approximately $60 \mathrm{~W} / \mathrm{kg}$ utilizing large area $200 \mu \mathrm{m}$ thick silicon solar cells.

A recent design, based on the earlier SAE and Olympus designs, is the APSA (advanced photovoltaic solar array), which is presently under development by JPL with NASA OAET funding (ref. 4). Prototype hardware, recently completed 
and demonstrated by TRW, utilizes a thin silicon cell $(2.5 \mathrm{~m}$ thick) and thin covers $(2 \mathrm{~m})$ along with a minimum mass design approach for all elements including the mast, canister, and stowage/launch container, in order to achieve $130 \mathrm{~W} / \mathrm{kg}$ for a wing size of $7.8 \mathrm{~kW}$ ( $\mathrm{fig} .1$ ). This basic design is projected to produce over $150 \mathrm{~W} / \mathrm{kg}$ at a wing size of approximately $12 \mathrm{~kW}$ (comparable in size to the SAE wing tested in 1984). For reduced sizes on the order of 2 to $3 \mathrm{~kW}$ the design is estimated to provide close to $100 \mathrm{~W} / \mathrm{kg}$. In the range of 1 to $3 \mathrm{~kW}$ wing size the estimates for APSA and FRUSA (with thin cells) are quite comparable. Advantages of either the fold out or roll out designs in this power range are most likely mission/spacecraft specific. However, it is unlikely that the roll out approach with a BISTEM type boom will scale to very high power levels ( 5 to $15 \mathrm{~kW}$ per wing) with mechanical performance competitive with the coilable longeron type designs.

\section{Advanced Concepts}

There is an additional type of array that can be considered, and that is the concentrated array system. In these designs cells are operated at high solar illumination intensities through the use of optical concentrating devices. Numerous concentrator concepts have been proposed over the years relying on reflective and refractive optical concentration schemes. Concentration ratios have been from very low (on the order of a factor of two) to very high (on the order of 100 or more). A purported advantage of these concepts has been the possibility of utilizing very high efficiency and costly solar cells. Since the actual amount of cell area can be very small a high volume cells process is not crucial. As long as the actual fabrication of the concentrating optics and structure is inexpensive the entire system cost can be cost compet itive.

To date concentrating arrays have not been flown in space, and until recently have not received serious development. Present work by the DOD does however have a significant hardware development effort with a potential flight application. These designs have been extremely heavy and provide a very low specific performance, in part because they are designed to survive multiple threats. Since the cell area is a small fraction of the total array area, it is reasonable to place heavy shielding on the front and rear surface of the solar cells to reduce particulate radiation damage.

An alternate approach is being examined by NASA. It relies on the use of refractive Fresnel lens and is being addressed to high specific performance since there is no concern for manmade threats. However, this design is not developed in a space qualified design at present and insufficient structural detail is available for accurate lack of information as to the behavior of concentrating optics in the space environment with respect to optical degradation.

Although for the majority of space missions a concentrating system is unlikely to of fer any real performance advantage over high efficiency planar array designs there is a potential payof in the ability to heavily shield the limited solar cell area from extremely severe particulate radiation environments without the kind of mass increase that would occur with a planar array. An example of such a radiation environment would be passage through thee earth's radiation belts from LEO to GEO using SEP. However at $t$ active this feature might be, substantial questions of array cost, packaging, deployment, 
environmental degradation, mass, and relatively stringent pointing requirements, still remain unanswered.

\section{Solar Cell Options}

Planar cells. - Figure 2 shows the projected efficiencies of various single junction solar cells in the Air Mass Zero (AMO) spectrum. As can be seen, there are a variety of solar cell options that can be considered for development. Each has its particular set of advantages and disadvantages for use in space power systems, and each has its distinct set of technical barriers to overcome. Cell types that are of particular interest for space missions requiring high power to weight ratios and radiation damage resistance will be brief ly discussed below.

Table 1 displays several solar cell types that are potential candidates for use on lightweight planar arrays in high natural radiation environments. The most mature of the cell types listed, in terms of production experience, commercial availability and spaceflight experience, is thin single crystal silicon. In 1988, the SBS-1A cylindrical communications satellite was launched (ref. 2). This spacecraft was powered by $14,1242 \times 6 \mathrm{~cm}, 62 \mu \mathrm{m}$ thick silicon solar cells $(27002 \times 2 \mathrm{~cm}, 200 \mu \mathrm{m}$ thick silicon solar cells were also used for battery charging). No major differences compared to standard thickness single crystal $\mathrm{Si}$ cells have been observed. The next most mature technology is the "standard" gallium arsenide solar cell. There are vendors in both the USA and Japan now capable of producing such cells, and the Japanese have at least one communications satellite powered entirely by GaAs cells in geosynchronous orbit. The laboratory efficiencies quoted for all cell types are for large area $(2 \times 2 \mathrm{~cm})$ cells except where noted. The expected date of availability in each case is a purely subjective estimate of the time required to move the technology from the laboratory through successful demonstration on a pilot production line, assuming that R\&D funding levels do not constrain any efforts to do so. Given sufficient funding, modest yields of cells with efficiencies at or near their projected values could be achieved in commercial production within a year or two of those dates. Based on the experience with GaAs cells, high yields of cells with efficiencies approaching 90 percent of projected values could reasonably be expected to be available within the same period.

Because of the wide ranging developmental status of the various cell types listed in Table 1 , it is not possible to provide an accurate comparison of expected in-space cell lifetimes. Definitive array performance predictions therefore cannot be made for cell types other than silicon until the equivalence between laboratory radiation damage tests and actual degradation under spaceflight conditions has been established. Comparison of cell performance at the same levels of laboratory fluences and energies is still a useful guide, however, since promising cell technologies can be identified for further development and testing. As long as the caveat on $1 \mathrm{MeV}$ electron equivalence is acknowledged, array end-of-life (EOL) performance estimates can be made as well, and are useful in identifying potential system level advantages or disadvantages that may be associated with a given solar cell technology. In addition, the comparison help to make clear what the desirable cell characteristics are from a system point of view, so that efforts to develop new cell types can be properly focussed on all the relevant technology issues. 
The factors which affect a given cell's performance, as well as its usefulness for a given mission application, range from its microscopic electronic and material properties to the macroscopic configuration of the device. Hence, any at tempt to establish a comparison between cell types must be carried out with extreme care. For example, there is a substantial body of evidence which suggests that the percent loss of power in thin silicon cells and GaAs cells (whe the $r$ on GaAs or Ge substrates and whether $p / n$ or $n / p$ ), is very nearly the same after equal doses of $1 \mathrm{MeV}$ electrons or high energy protons in laboratory tests. A significant advantage accrues to GaAs cells, however, when the expected array on-orbit operating temperature is taken into account, and the comparison is made on an absolute basis. Figure 3 shows such a comparison. In this case, the factor which is important is the higher badgap of GaAs, which results in cells with higher actual output at modestly elevated temperatures compared to $\mathrm{Si}$ cells. The value of this advantage is quickly lost when considering lightweight array technology such as the APSA because of the higher density of GaAs compared to Si (approximately a factor of two). Unless the GaAs cells are made thin, or mounted on a thin, lightweight substrate or superstrate, higher array EOL power is available with thin silicon. GaAs on thin Ge substrates, or CLEFT GaAs cells (ref. 5) on $62 \mu \mathrm{m} \mathrm{Si}$ substrates can provide substantially higher BOL and EOL array specific powers, however. GaAs on $75 \mu \mathrm{m}$ thick Ge substrates are currently under development in an Air Force manufacturing technology program at Applied Solar Energy Corporation. CLEFT GaAs cells on $62 \mu \mathrm{m}$ silicon substrates have been demonstrated by the KOPIN Corporation (ref. 6). Efficiencies approaching 20 percent $A M O$ at $25^{\circ} \mathrm{C}$ can be expected to be achieved in both cases, with radiation damage resistance characteristics similar to that already observed in GaAs.

InP cells have only slightly lower projected efficiencies than GaAs because of the slightly lower energy bandgap (1.35 versus $1.43 \mathrm{eV}$ for GaAs). Although the density of InP is about 15 percent lower than that of GaAs so that some improvement in array specific power could be realized by directly substituting InP for GaAs, the major reason for interest in cells mad from this material is their dramatic resistance to electron and proton radiation damage, as revealed in laboratory tests. The significantly higher EOL/BOL power ratio observed more than compensates for the slightly lower BOL power such cells can be expected to have. Figure 4 shows some recent results from $1 \mathrm{MeV}$ electron irradiations. The small degradation in normalized power approaches that observed in the thin film technologies such as CuInSe2 (CIS) and a amorphous silicon (refs. 7 and 8). Also of significance, all of the approaches available for reducing the mass of GaAs cells are also available for the InP cells: hetereoepitaxial InP on alternative (most likely Ge or Si) substrates, and CLEFT (or other peeled film) InP cells on Si or glass. Each of the above approaches are under investigation, and feasibility has been established in every case. what remains is to achieve the expected efficiencies in the devices and to test their radiation resistance. Success in developing an InP on Si structure, whether mechanically attached or heteroepitaxially grown, would result in a device with the mass equivalence of $75 \mu \mathrm{m}$ of silicon, an AMO efficiency approaching 20 percent, and a relative power loss from radiation damage perhaps less than one-tenth that observed in thin silicon or GaAs, especially at the high fluences that would be encountered in a LEO to GEO transfer orbit. Considerable cell development and testing is required before reliable engineering estimates of array performance can be made, but the potential payoff for the effort will be a totally new photovoltaic power system capability: long term operation in high radiation fluence environments. APSA EOL specific powers approaching $200 \mathrm{~W} / \mathrm{kg}$ after a year in the mid latitudes may be possible. 
In principle, certain thin film cells are projected to have single junction efficiencies approaching single crystal cells. In practice, all have fallen far short of that level of performance. The currently favored candidate for achieving relatively high performance in a thin film is CIS. AMO efficiencies slightly above 11 percent have been measured in small are devices. The resistance of such cells to damage from both $1 \mathrm{MeV}$ protons are outstanding (ref. 7). The normalized power degradation in GaAs cells af ter a fluence of E12 $1 \mathrm{MeV}$ protons is nearly five times greater than in CIS cells. Furthermore, after a fluence of $1 E 171 \mathrm{MeV}$ electrons CIS exhibits essentially no power loss. There is at present no suitable explanation for the observed behavior of such cells. Commercial CIS devices are made on thick glass substrates, al though the possibility exists to produce them on $50 \mu \mathrm{m}$ thick glass. A small exploratory effort is currently underway to produce them on thin, flexible substrates, which would be a logical extension of technology, both to increase array specific power, and to reduce cost (ref. 9). The lower cell efficiency will result in a lower value of area specific power $\left(W / \mathrm{m}^{2}\right)$ compared to that achieved with high efficiency single crystal cells, but EOL values can in fact be higher, depending on the total fluence accumulated during the mission. Again, data are insufficient to make precise predictions, but CIS cells are clearly promising.

Amorphous silicon is a second thin film cell type that has been of interest for space applications, primarily because of its potential for achieving extremely high specific power, even at modest efficiencies. Amorphous silicon single junction cells are projected to have efficiencies around 12 percent AMO, and can be deposited directly on flexible, lightweight, large area substrates. To date, small area cells have been fabricated on stainless steel and glass substrates with efficiencies approaching 10 percent AMO, while direct deposition on Kapton has produced cells with efficiencies ranging up to 5.5 percent AMO (ref. 10). The latter have been produced on $50 \mu \mathrm{m}$ thick Kapton in a rollto-roll process, and have a blanket specific power with a nonspace qualified encapsulant of $800 \mathrm{~W} / \mathrm{kg}$. Improvement in efficiency to 10 percent and deposition on $25 \mu \mathrm{m}$ thick Kapton substrates has the potential for achieving $3 \mathrm{~kW} / \mathrm{kg}$ at the blanket level. Radiation damage resistance has not been fully characterized, but appears to be quite good, especially to proton damage (ref, 8). Early results indicate behavior comparable to that observed in CIS. A major problem that remains unresolved is the large light-induced degradation known as the Staebler-Wronski effect. Long term exposure (hundreds of hr) to light causes a 15 to 25 percent loss of power (a significant fraction of which can be recovered by annealing in the dark), depending on the specific cell design. It is expected that better control of the effect can be achieved, so that degradation may well be limited to less than 10 percent over the first several tens of hr of operation, but no clear understanding of this phenomenon yet exists to assure its elimination.

\section{Concentrator Cells}

Al though concentrator arrays cannot compete with advanced, lightweight planar array designs for high specific powers $(\mathrm{W} / \mathrm{kg})$, they can provide a potentially cost-effective approach for achieving extremely high area power densities at specific powers exceeding today's lightweight planar array technology (e.g., the Space Station Freedom baseline is $\overline{6} 6 \mathrm{~W} / \mathrm{kg}$ ). They are presumed to be cost-effective on the basis that the total area to be covered by expensive semiconductor devices can be reduced approximately by a factor equal to the inverse of the concentration ration, and that less expensive optical devices 
can be fabricated to achieve the performance desired Lightweight optical elements will also be required, with the result that significant radiation resistance will still be required of the solar cell structure itself, since the optical element will not provide a major amount of shielding. The addition of small area, thick coverglasses to the concentrator cells can be of substantial benefit, and will not add greatly to the total mass of such an array. Alternatively, the concentration level and the cell operating temperature can be adjusted within a wide set of limits to take advantage of any annealing characteristics of potential concentrator cells. The former approach applies to the use of the recently developed high efficiency tandem cell structure (ref. 11), which has measured efficiencies in excess of 30 percent at modest concentration levels $(100 x$ to $200 x)$ and a $25{ }^{\circ} \mathrm{C}$ operating temperature. Area power densities of $300 \mathrm{~W} / \mathrm{m}^{2}$ or more are feasible with this approach, with estimated values of specific power exceeding $120 \mathrm{~W} / \mathrm{kg}$. There is insufficient data to accurately project radiation damage degradation for such an array, particularly to the optical element, but the cell can reasonable to expected to incur little degradation for fluences equivalent to long term exposure in the radiation belts.

The second approach for achieving radiation hardness with lightweight concentrator array technology takes advantage of the unique annealing behavior exhibited by InP solar cells at temperatures in the range from 100 to $125{ }^{\circ} \mathrm{C}$, and of the potential for light-induced annealing at concentrated sunlight levels (refs. 12 and 13). Although both effects need further investigation, the potential exists to achieve complete radiation hardness through continuous annealing of the damage as it occurs. If successfully demonstrated, such cells would be able to operate indefinitely in the heart of the radiation belts, or any other naturally occurring radiation environment. There is as yet no data on the survivability of the rest of the array components, particularly the optical element itself, but development continues at a modest (funding-limited) pace. This approach would make feasible a radiation hard concentrator array with a specific power greater than $90 \mathrm{~W} / \mathrm{kg}$, and an area power density in excess of $200 \mathrm{~W} / \mathrm{m}^{2}$, and is a nearer term option than an array with the 30 percent tandem cells discussed above. An interesting feature of the concentrator approach in general is that the array can be designed to be "technology transparent" to the actual cell type being used, so that as new, higher efficiency cells become available, they can be used without the need for major array redesign.

\section{Photovol taic Array System}

Performance projections. - Array electrical performance has been examined for two representative solar electric propulsion missions. These include a LEO-GEO transfer orbit and an interplanetary or earth-lunar excursion commencing beyond the region of the Van Allen belts. Table 2 presents results for a five year "interplanetary" SEP mission. Array specific performance is given for the 1 AU conditions. All designs were sized to provide the same power at end of mission $(7 \mathrm{~kW})$. The results are shown for the baseline APSA design (thin silicon cells and covers, i.e., minimum shielding), a conventional rigid design using thin silicon cells, and an APSA derivative design using thin film copper indium diselenide (CIS) cells. It should be noted that the data for the CIS array performance is based on preliminary data obtained with a limited number of development cells. For this application, which can be characterized as a relatively moderate radiation environment, no performance benefit follows from the use of rigid array technology. The rigid technology yields a slightly 
lower area and may be lower in cost,but incurs a significant mass penalty. The use of an advanced thin film cell, even with moderate efficiency, will save both mass and area, as long as high radiation resistance can be maintained.

Table 3 presents the results for the possible LEO-GEO transfer lasting 200 days. The transfer orbit particulars were calculated for the low thrust performance of a solar electric propulsion system. The lightweight APSA type system, al though subject to high radiation degradation, is still much lower in mass than a rigid array design showing reduced degradation. The power system mass is an important factor where increased mass array mass will require a corresponding decrease in payload to maintain an equal transit time. Although a greater mass could be used, the increase in transit time would in turn lead to increased damage. The most intriguing options is that of the APSA array with a thin film radiation resistance cell, such as might be available by the end of the next decade, for not only is it the least massive but it also has the least degradation, and consequently smallest area. The importance of the development of such lightweight cells for use with lightweight array technology is clear, particularly where substantial radiation will be experienced.

\section{CONCLUSIONS}

There are clearly a large number of photovoltaics options for space applications. Not only do a wide range of array technologies exist, but cell options have increased recently with the near production readiness of $\mathrm{GaAs} / \mathrm{Ge}$ cells, and a number of new devices are in development which may be available by the end of the decade. Each array or cell type offers advantages and disadvantages in terms of efficiency, cost, radiation resistance, and ease of assembly. Consequently the optimum for any mission will depend on the mission particulars such as stowage volume, power requirements, and environmental conditions, for example. It is likely that future SEP applications, excluding possible test flights and demonstrations, will require relatively high powered systems, with high specific performance. Such missions are most likely to favor array concepts such as the APSA. It is likely that the early missions will rely on the use of baseline APSA technology with later missions employing modified versions as advanced cells (thin film and thin stacked devices) become available. The impact of various cell technologies on the performance of the APSA is shown in figure 5. The two regions examined for possible cell enhancements include III to IV devices, and thin film devices of various compositions (including "thin film" cleft GaAs). The advantage of low cell mass is evident from the figure. Relatively moderate efficiency thin film cells will lead to a lower mass array (with a potential for specific performance greater than $200 \mathrm{~W} / \mathrm{kg}$ ) than very high efficiency "thick" cells, although the latter will be of reduced area. Concentrator systems are considered less likely candidates, particularly for the near future. However, significant progress in concentrator array technology could make that concept attractive, especially as a means for using very high efficiency cells in a radiation shielded package.

\section{ACKNOWLEDGEMENT}

The work described herein was carried out by the Jet Propulsion Laboratory, California Institute of Technology, under contract to the National Aeronautics and Space Administration, and by NASA Lewis Research Center. 


\section{REFERENCES}

1. Wilding-White, T.M.: Jane's Pocket Book of Space Exploration. Collier Books, 1976.

2. Fodor, J.S.; Goldhammer, L.J.; and Allan, J.B.: SBS-1A Solar Arrays with Ultrathin, High Efficiency Solar Cells. Proceedings of the 23rd IECEC, AMSE, vol. 3, 1988, pp. 79-83.

3. Wolff, G.: The Flight of the Frusa. Proceedings of the 9 th IEEE Photovoltaics Specialists Conference, IEEE, 1972, pp. 240-253.

4. Kurland, R.M. and Stella, P.M.: Advanced Photovoltaic Solar Array Program Status. Proceedings of the 24 IECEC, Vol. 2, IEEE, 1989, pp. 829-834.

5. McCelland, R.W.; Bozler, R.W.; and Fan, J.C.C.: A Technique for Producing Epitaxial Films on Reusable Substrates. Appl. Phys. Let t., vol. 37, no. 6 , Sept. 15, 1980, pp. 560-562.

6. Flood, D.: Private Communication Kopin Corp., Taunton, Ma, 1990.

7. Kim, N.P., et al.: Development of Tandem Cells Consisting of GaAs Single Crystal and CuInSe 2 /CdZnS Polycrystalline Thin Films. Space Photovoltaic Research and Technology 1988, NASA CP-3030, 1988, pp. 138-145.

8. Hanak, J.J., et al.: Ultralight Amorphous Silicon Alloy Photovoltaic Modules for Space Applications. Space Photovoltaic Research and Technology 1986, NASA CP-2475, 1986, pp. 99-110.

9. Landis, A.; Bailey, G.; and Flood, D. J.: Advances in Thin-Film Solar Cells for Lightweight Space Photovoltaic Power. NASA TM-102017, 1989.

10. JPL Procurement with International Solar Electric Technolgy, Inglewood, CA, Apr. 1990.

11. Frass, L.M., et al.: High Efficiency GaAs/GaSb Tandem Solar Cells and Circuit Cards. Proceedings of the 24th IECEC, vol. 2, IEEE, 1989, pp. 815-820.

12. Ando, K.; and Yamaguchi, M.: Radiation Resistance of InP Solar Cells Under Light Illumination. Appl. Phys. Lett., vol. 47, no. 8, Oct. 15, 1984 , pp. 846-848.

13. Yamaguchi, M.; Uemura, C.; and Yamamoto, A.: Radiation Damage in InP Single Crystals and Solar Cells. J. Appl. Phys., vol. 55, no. 6, Mar. 15, 1984, pp. 1429-1436. 
adVANCED PLANAR SPACE SOLAR CELl teCHNOLOGY STATUS

\begin{tabular}{|c|c|c|c|c|c|c|c|}
\hline CELL TYPE & CelT STRUCTURE & $\begin{array}{l}\text { PROJECTEO } \\
\text { EFF ICIENCY }\end{array}$ & $\begin{array}{l}\text { LABORATORY } \\
\text { EFFICIENCY }\end{array}$ & $\begin{array}{l}\text { COMMERCIAL } \\
\text { EFFICIENCY }\end{array}$ & $\begin{array}{c}\text { (1E15 } \mathrm{cm}^{-2^{\circ}}{ }_{1 \mathrm{MeV}} \\
\text { ELECIRONS) }\end{array}$ & $\begin{array}{c}\mathrm{P} / \mathrm{P}^{\circ} \\
\text { (E12 } \mathrm{cm}^{-2} 10 \mathrm{MeV} \\
\text { PROTONS) }\end{array}$ & $\begin{array}{l}\text { ESTIMATED DATE } \\
\text { AVA ILABLE }\end{array}$ \\
\hline THIN SILICON & $\begin{array}{l}62 \text { um SUBSTRATE } \\
n / P \text { DIFFUSED BSF, BSR }\end{array}$ & $14.5 \%$ & $14.5 \%$ & $13.7 \%$ & 0.74 & $\begin{array}{l}\text { DAMAGE EQUIVALENCE } \\
\text { TO IMeV PROTONS } \\
\text { KNOWN }\end{array}$ & NOW \\
\hline GaAs & $\begin{array}{l}300 \mu \mathrm{m} \text { SUBSTRATE } \\
n / p, p / n \text { OMCVD, LPE }\end{array}$ & $23 \%$ & $21.5 \%$ & $20 \%$ & 0.74 & 0.8 & HOH \\
\hline GaAs/Ge & $\begin{array}{ll} & 75 \text { um SUBSTRATE } \\
10 & \text { un CELL, p/n OMCVO }\end{array}$ & $23 \%$ & $20.5 \%$ & $20 \%$ & 0.74 & 0.8 & HOW \\
\hline CLEFT GaAs/Si & $\begin{array}{l}62 \mu \mathrm{m} \text { SUBSTRATE, } 6 \mu \mathrm{m} \\
\text { CELL } \mathrm{n} / \mathrm{p}, \mathrm{p} / \mathrm{n} \text { OMCVD }\end{array}$ & $23 \%$ & $20 \%$ & - & 0.74 & 0.8 & 1994 \\
\hline $\ln P$ & $\begin{array}{c}300 \underset{n}{\mu m} \text { SUBSTRATE } \\
\text { OHCVD }\end{array}$ & $22 \%$ & $19 \%$ & - & 0.975 & 0.9 & 1993 \\
\hline $\operatorname{InP} / G e$ & $\begin{array}{c}75 \mu \mathrm{m} \text { SUBSTRATE } \\
10 \mu \mathrm{m} \text { CELL, n/p OMCVO }\end{array}$ & $20.5 \%$ & $9 \%$ & - & 0.975 & - & 1995 \\
\hline $\operatorname{InP} / S i$ & $\begin{array}{c}62 \mu \mathrm{m} \text { SUBSTRATE* } \\
10 \mu \mathrm{m} \text { CELL, n/p OMCVD }\end{array}$ & $18.5 \%$ & $7 \%$ & - & - & - & 1997 \\
\hline CuInSe2 & $\begin{array}{l}5 \mu m \text { FILM, } 50 \mu \mathrm{m} \\
\text { GLASS SUBSTRATE* }\end{array}$ & $16 \%$ & $11 \%$ & - & 20.98 & $0.9(1 \mathrm{MeV})$ & 1993 \\
\hline
\end{tabular}

-PROJECTED THICKNESS

ALL RADIATION DAMAGE RESULTS WITHOUT COVERGLASSES

Table 1. Advanced Planar Space Solar Cell Technology Status

\begin{tabular}{|c|c|c|c|c|}
\hline & \multicolumn{2}{|c|}{$\begin{array}{c}\text { SPECIFIC PERFORMANCE } \\
(W / \mathrm{kg})\end{array}$} & \multirow{2}{*}{$\begin{array}{l}\text { ARRAY } \\
\text { MASS } \\
(\mathrm{kg})\end{array}$} & \multirow{2}{*}{$\begin{array}{c}\text { AELATIVE AREA FOR } \\
\text { SAME EOL POWER } \\
(=7 \mathrm{~kW})\end{array}$} \\
\hline & BOL & EOL & & \\
\hline APSA (3 mil SHIELD) & 130 & 94 & 74 & 1.00 \\
\hline $\begin{array}{l}\text { CONVENTIONAL RIGID } \\
\text { (12 mil COVER) }\end{array}$ & 30 & 24 & 292 & 0.90 \\
\hline APSA (CulnSe $\left.)_{2}\right)^{* *}$ EST. & 165 & 155 & 45 & 0.95 \\
\hline
\end{tabular}

- FRONT AND REAR SIDE EQUIVALENT SHIELDING

" ASSUME $11 \%$ CELL EFFICIENCY, 3 mil SHIELDING FAONT AND REAR, SILICON DAMAGE EOUIVALENCE

Table 2. Array Performance for 5 Year Interplanetary SEP Mission

\begin{tabular}{|l|c|c|c|c|}
\hline & \multicolumn{2}{|c|}{$\begin{array}{c}\text { SPECIFIC PEAFORMANCE } \\
(\text { W/kg) }\end{array}$} & $\begin{array}{c}\text { ARRAY } \\
\text { MASS } \\
(\mathrm{kg})\end{array}$ & $\begin{array}{c}\text { RELATIVE AREA FOR } \\
\text { SAME EOL POWER } \\
(-7 \mathrm{~kW})\end{array}$ \\
\cline { 2 - 6 } & BOL & EOL & 140 & 1.00 \\
\hline APSA (3 mil SHIELD) & 130 & 50 & 350 & 0.57 \\
\hline $\begin{array}{l}\text { CONVENTIONAL RIGID } \\
\text { (12 mil COVER) }\end{array}$ & 30 & 20 & 54 & 0.56 \\
\hline APSA (CulnSe, ${ }_{2}^{* *}$ EST. & 155 & 130 & & \\
\hline
\end{tabular}

" Front AND REAR Side equivalent ShIELding

* ASSUME $11 \%$ CELL EFFICIENCY, 3 mil SHIELDING FRONT AND REAR, SILICON DAMAGE EQUIVALENCE

Table 3. Array Performance for 200 day LEO-GEO SEP Transit 


\section{ORIGINAI PAGE IS \\ OF POOR QUALITY}

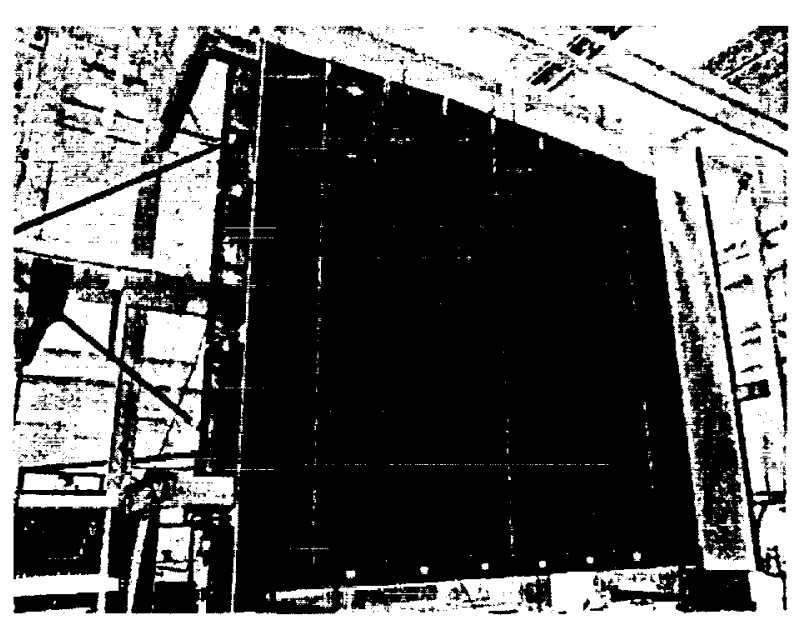

Fig. 1. Deployed Prolotype APSA Wing

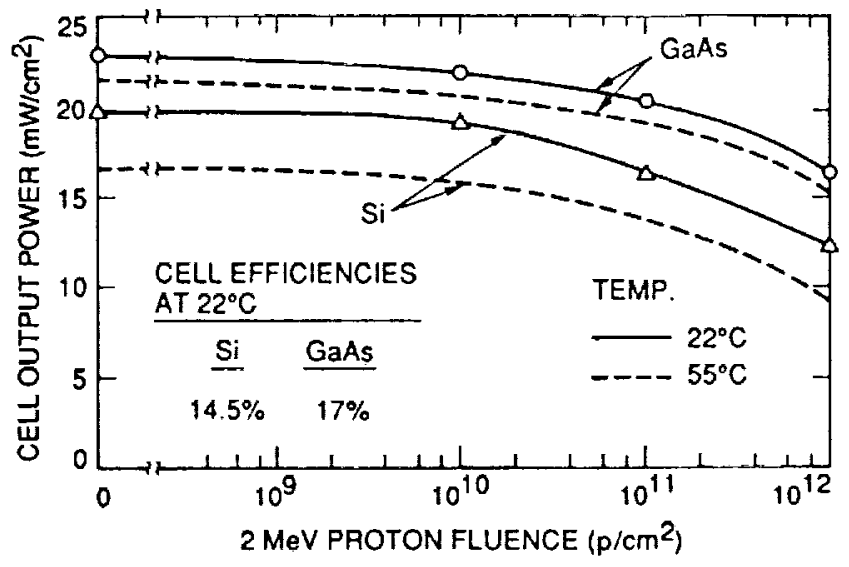

Fig. 3.

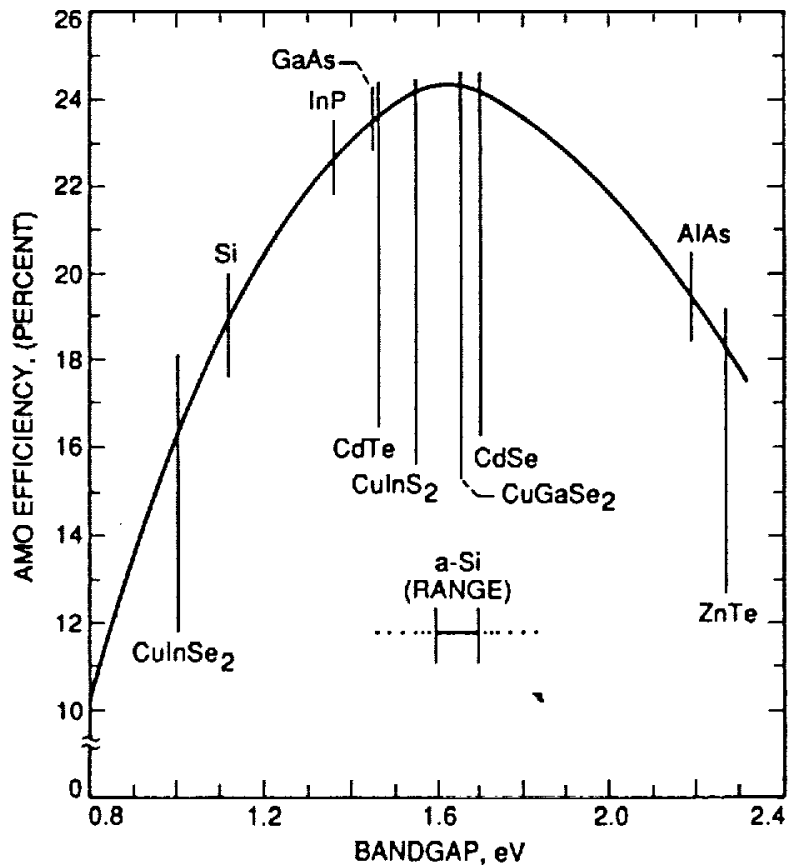

Fig. 2. Single Junction Solar Cell Erficiencies as a Function of Energy Bandgap

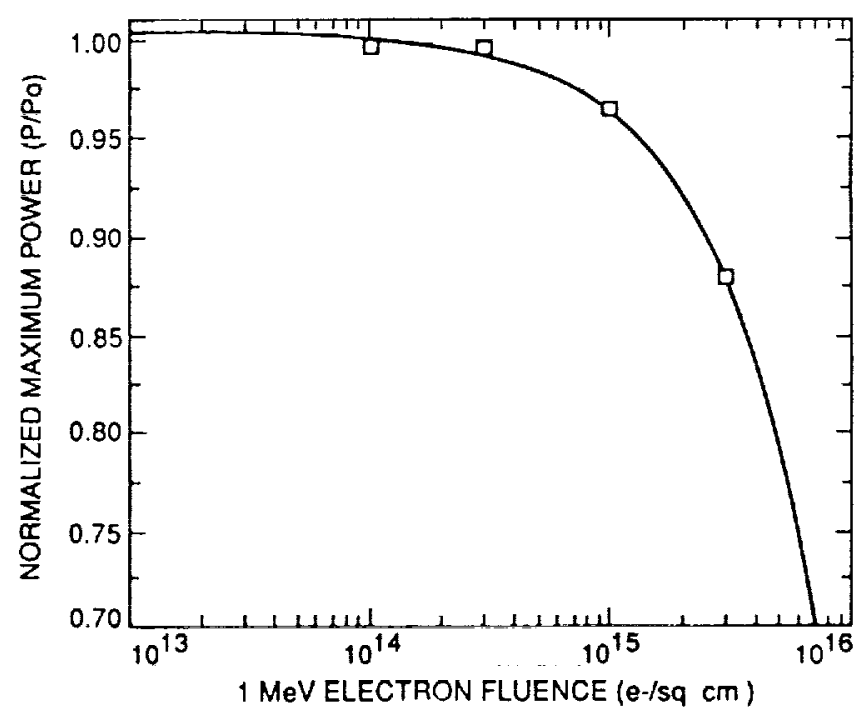

Fig. 4. Normalized Power ys. $1 \mathrm{MeV}$ Electron Fluence for In P n/p Solar Cells 


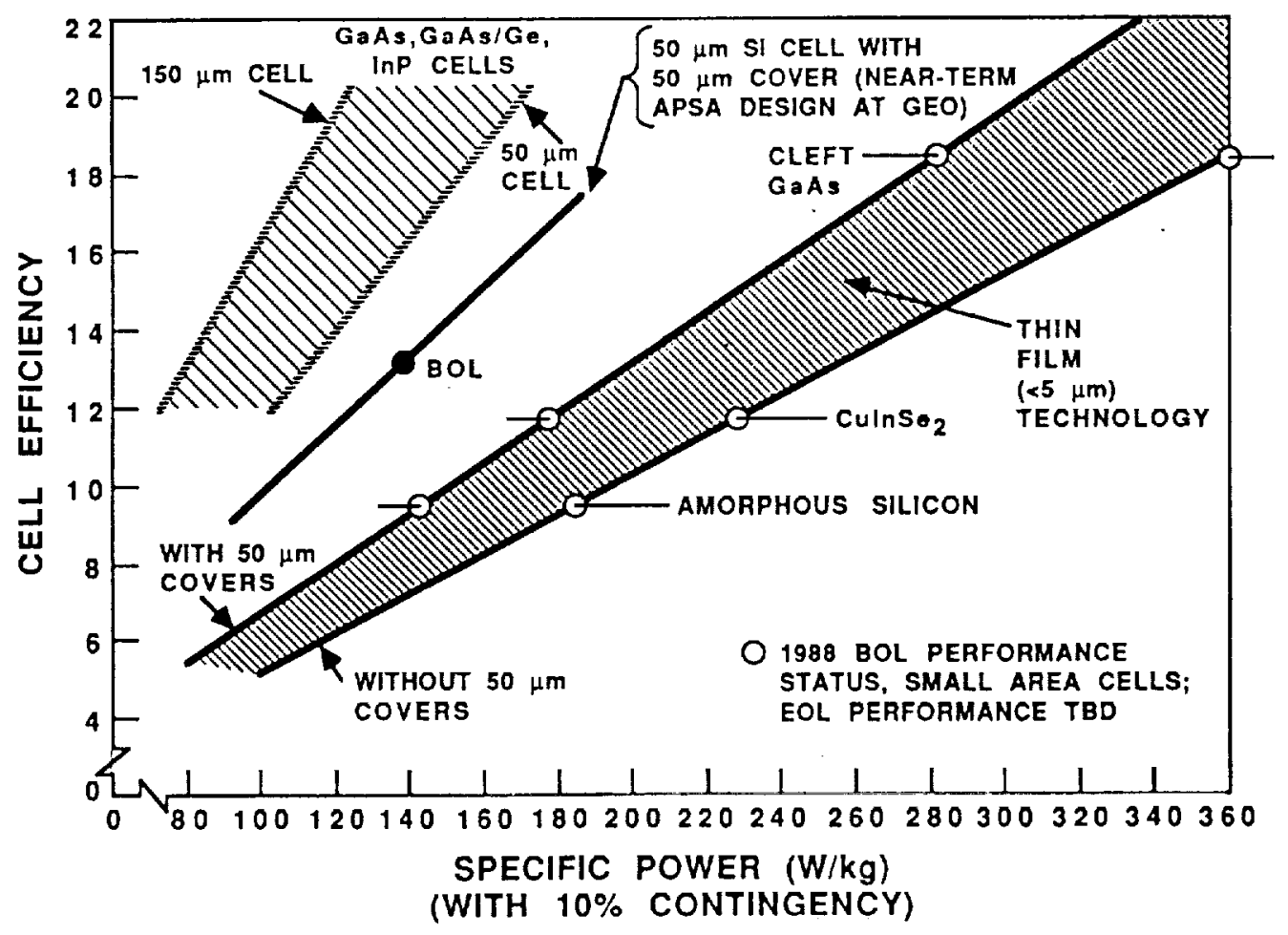

Fig. 5. Impact of Cell Type and Erriciency on APSA Specific Performance 


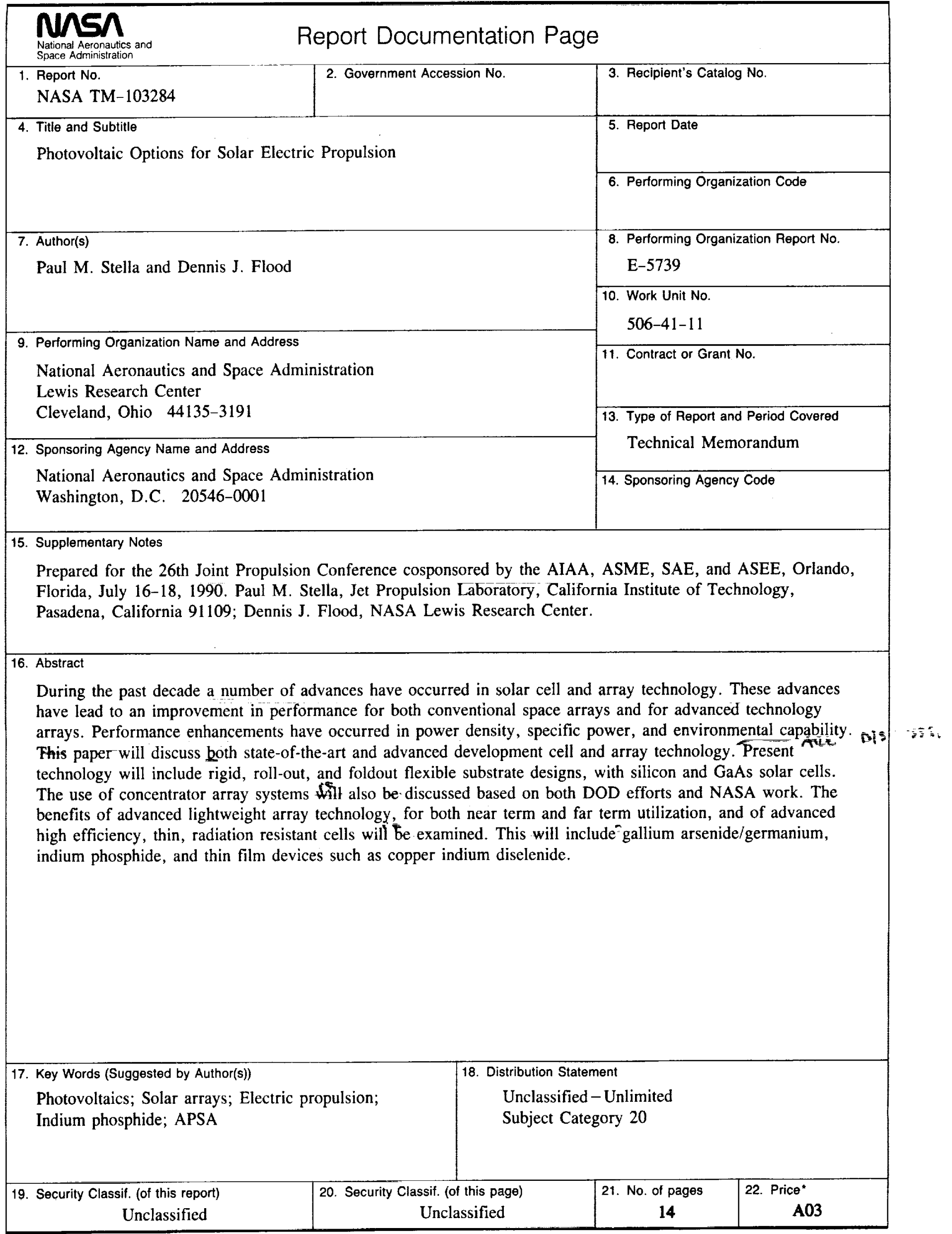

